Biocompatible Ionic Liquid-mediated Micelles for Enhanced

Md. Korban Ali ${ }^{\dagger}$, Rahman Md Moshikur ${ }^{\dagger}$, Rie Wakabayashi ${ }^{\dagger}$, , Muhammad Moniruzzaman\#, and Masahiro Goto ${ }^{\dagger, \S, \|, *}$

8

†Department of Applied Chemistry, Graduate School of Engineering, Kyushu University, 744

Department of Chemistry, Jashore University of Science and Technology, Jashore-7408, Bangladesh.

${ }^{\#}$ Chemical Engineering Department, Universiti Teknologi PETRONAS, 32610 Seri Iskandar, Perak, Malaysia.

$\S$ Advanced Transdermal Drug Delivery System Center, Kyushu University, 744 Motooka, Nishi-ku, Fukuoka 819-0395, Japan.

"Division of Biotechnology, Center for Future Chemistry, Kyushu University, 744 Motooka,

The SI contains 10 pages with 1 reaction scheme, 2 tables and 9 figures.

*Corresponding author: Prof. Masahiro Goto. E-mail: m-goto@mail.cstm.kyushu-u.ac.jp; Fax: +8192802 2810; Tel: +81928022806.

3 


\begin{tabular}{ccccc}
\hline Formulations $^{\text {a }}$ & $\begin{array}{c}\text { Ethanol } \\
(\mathrm{mg})\end{array}$ & $\begin{array}{c}\text { SAIL[Cho][Ole] } \\
(\mathrm{mg})\end{array}$ & Tween-80 (mg) & Span-20 (mg) \\
\hline $\begin{array}{c}\text { [Cho][Ole]-based } \\
\text { MF (F1) }\end{array}$ & - & 33.33 & - & 16.67 \\
$\begin{array}{c}\text { [Cho][Ole]-based } \\
\text { MF (F2) }\end{array}$ & - & 25 & - & 25 \\
$\begin{array}{c}\text { [Cho][Ole]-based } \\
\text { MF (F3) }\end{array}$ & - & 16.67 & - & 33.33 \\
$\begin{array}{c}\text { Tween 80-based } \\
\text { MF (F4) }\end{array}$ & - & - & 33.33 & 16.67 \\
Ethanol based (F5) & 100 & - & - & - \\
\hline
\end{tabular}

\section{Synthesis and Characterization of SAIL[Cho][Ole]}

The SAIL[Cho][Ole] was synthesized by our earlier reported procedure (Scheme S1). ${ }^{1}$ Briefly, choline chloride $(5 \mathrm{mg}$ ) was strongly stirred with an excess of silver oxide in presence of water. Then the mixtures were kept in dark place with continuous stirring at room temperature. After $2 \mathrm{~h}$, the mixtures were filtered, and the resultant solution was then evaporated to get choline hydroxide. The obtained choline hydroxide was then neutralized with an equimolar quantity of oleic acid in presence of methanol. After complete neutralization, the resulting solution was evaporated at $40{ }^{\circ} \mathrm{C}$ under $20 \mathrm{hPa}$, and then lyophilized for $48 \mathrm{~h}$ to eliminate residual water. ${ }^{1} \mathrm{H}$ and ${ }^{13} \mathrm{C}$ NMR, FT-IR spectroscopy and elemental analysis were used to confirm the purities and structures of the synthesized compounds ${ }^{2}$.

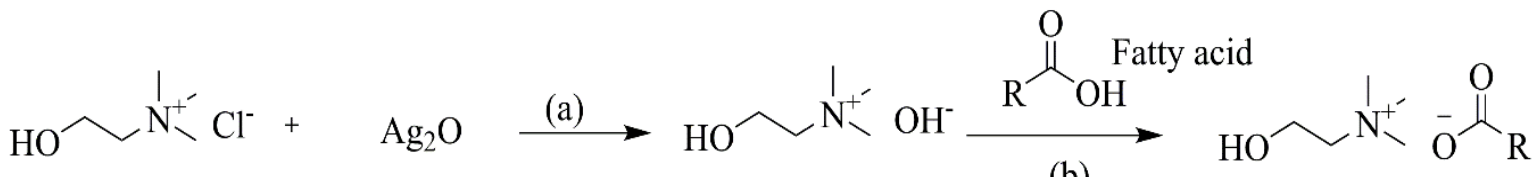
Choline chloride
Silver oxide
Choline hydroxide
Choline fatty acid IL

(b)

Scheme S1. General process for the synthesis of the SAIL[Cho][Ole]. (a) Precipitation of silver chloride in water at room temperature for $2 \mathrm{~h}$ in the dark to obtain choline hydroxide. (b) Stirring choline hydroxide and the oleic acid in methanol at room temperature for $24 \mathrm{~h}$ yields the SAIL[Cho][Ole].

Table S1: Preparation of PTX loaded formulations for skin permeation study

${ }^{\mathrm{a}}$ Formulations were prepared with $5 \mathrm{mg}$ PTX in $1 \mathrm{~mL}$ IPM 
Table S2. Chemical shifts and observations determined by ${ }^{1} \mathrm{H}$ NMR

\begin{tabular}{|c|c|c|c|}
\hline $\begin{array}{l}\text { PTX-Surfactant } \\
\text { system }\end{array}$ & $\begin{array}{c}{ }^{1} \mathrm{H} \text { NMR chemical } \\
\text { shift range in } \delta \\
\text { (ppm) for aromatic } \\
\text { and -OH } \\
\text { protons of PTX }\end{array}$ & H in PTX structure & $\begin{array}{l}\text { Observations after } \\
\text { Formation of MF }\end{array}$ \\
\hline \multirow[t]{6}{*}{ Pure PTX } & $7.91(d)$ & $\mathrm{Ar}-\mathrm{C}(=\mathrm{O}) \mathrm{OC}(\mathrm{C}) \mathrm{C}-$ & \\
\hline & $7.84(d)$ & $\operatorname{Ar}-\mathrm{C}(=\mathrm{O}) \mathrm{N}-$ & \\
\hline & $7.57-7.68(\mathrm{~m})$ & $\operatorname{Ar}-\mathrm{C}(=\mathrm{O}) \mathrm{OC}(\mathrm{C}) \mathrm{C}-$ & \\
\hline & $7.43-7.49(\mathrm{~m})$ & $\operatorname{Ar}-\mathrm{C}(=\mathrm{O}) \mathrm{N}$ & \\
\hline & $7.32-7.35(\mathrm{~m})$ & Ar-C-N- & \\
\hline & $6.25(\mathrm{~s})$ & $-\mathrm{OH}$ & \\
\hline \multirow[t]{6}{*}{ PTX loaded micelles } & $7.95(d)$ & $\operatorname{Ar}-\mathrm{C}(=\mathrm{O}) \mathrm{OC}(\mathrm{C}) \mathrm{C}$ & i) Significant deshielding \\
\hline & $7.88(d)$ & $\operatorname{Ar}-\mathrm{C}(=\mathrm{O}) \mathrm{N}$ & observed for all the \\
\hline & 7.64--7.76(m) & $\operatorname{Ar}-\mathrm{C}(=\mathrm{O}) \mathrm{OC}(\mathrm{C}) \mathrm{C}$ & protons. \\
\hline & $7.53-7.56(\mathrm{~m})$ & $\operatorname{Ar}-\mathrm{CH}-\mathrm{C}(=\mathrm{O}) \mathrm{N}$ & ii) Downfield chemical \\
\hline & $7.32-7.39(\mathrm{~m})$ & Ar-C-N & shift for all protons \\
\hline & $6.57(\mathrm{~s})$ & $-\mathrm{OH}$ & \\
\hline
\end{tabular}

56 
A)

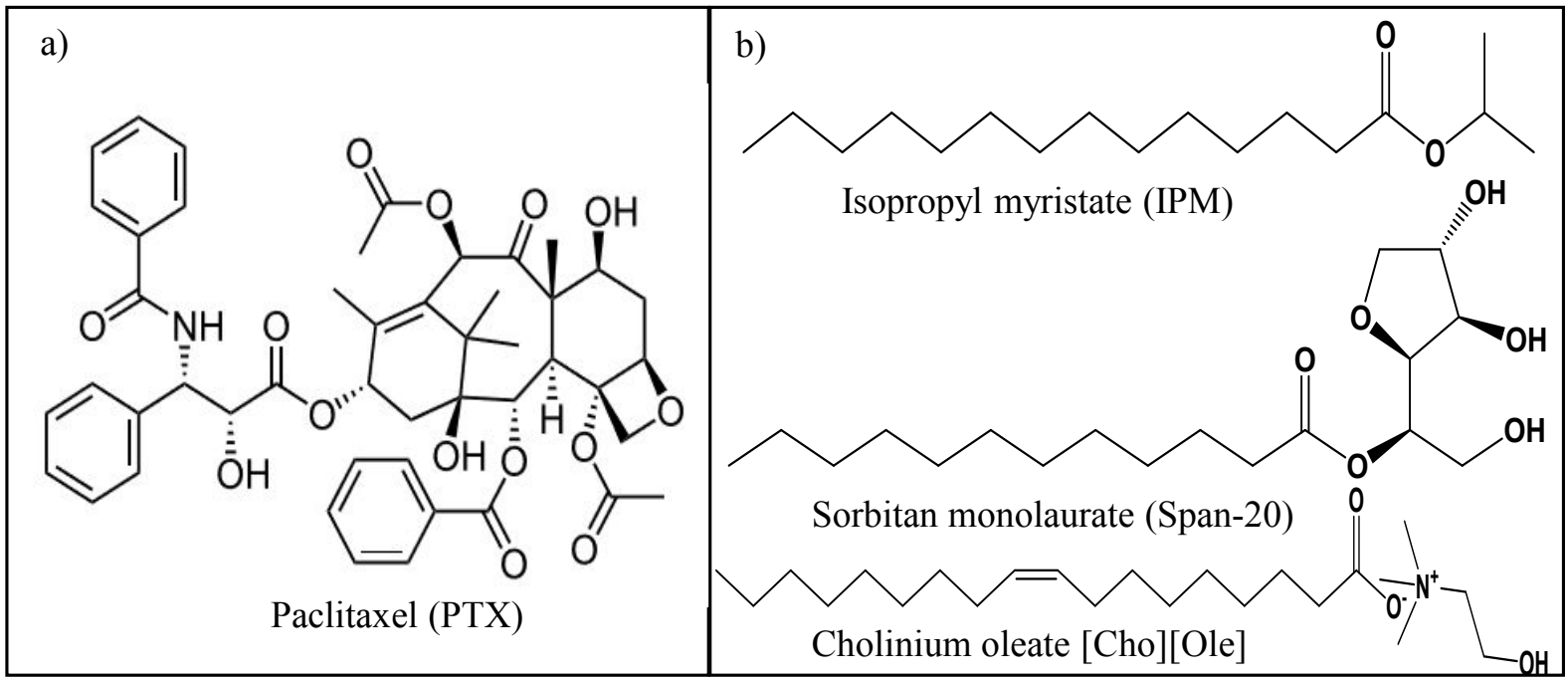

73

B)

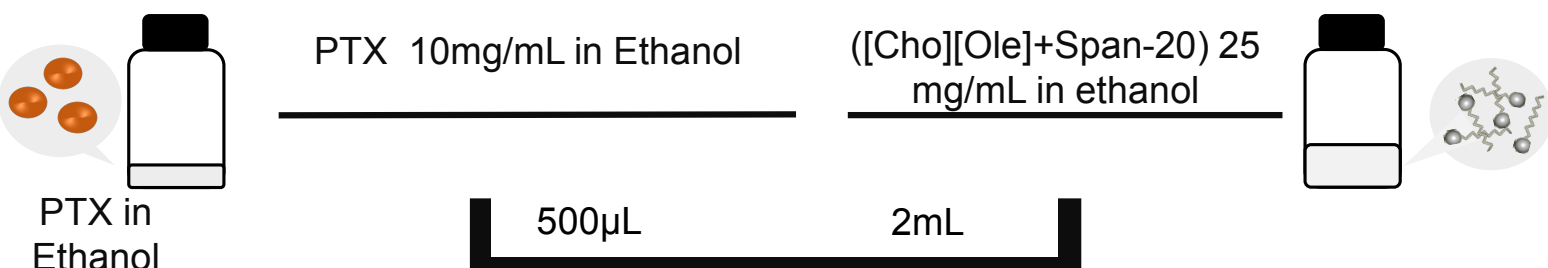

Ethano

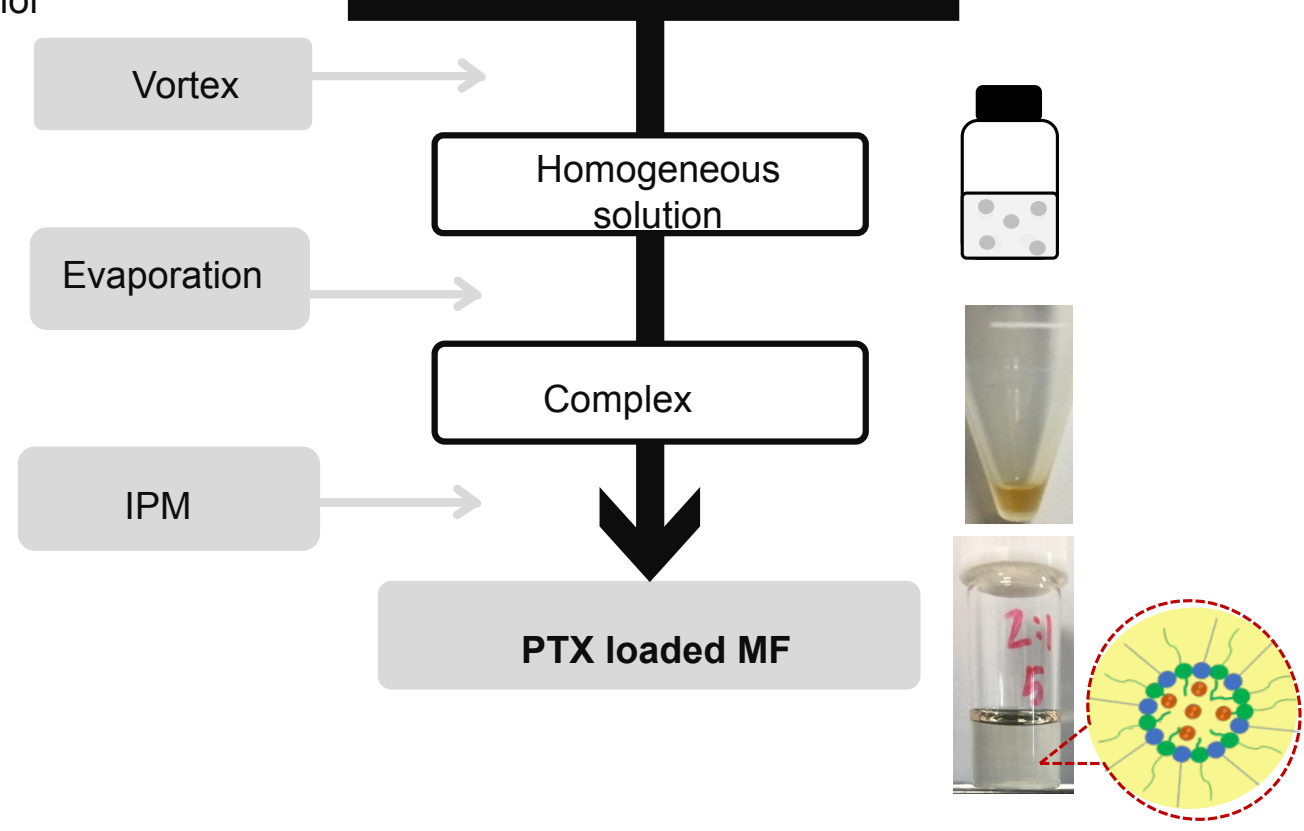

Figure S1: (A) Molecular structure of Paclitaxel (a) and components of MF Preparation (b).

(B) Preparation scheme for PTX loaded MF 


\section{Synergistic micellization effects between SAIL[Cho][Ole] and Span-20 in IPM.}

To investigate the synergistic effect between SAIL[Cho][Ole] and Span-20, the surfactants SAIL[Cho][Ole] and Span-20 were mixed individually and also blend of SAIL[Cho][Ole]/Span-20 with IPM where the total concentration of surfactant were $5 \%$. Then all the samples were vigorously stirrer using a vortex mixer (Scientific industries, Inc, USA) for 30s at $3000 \mathrm{rpm}$. A confocal microscope (CLSM 700, Carl Zeiss; Oberkochen, Germany) imaging system was then used to find bright-field images of the samples at time interval 0 and 30 minutes.
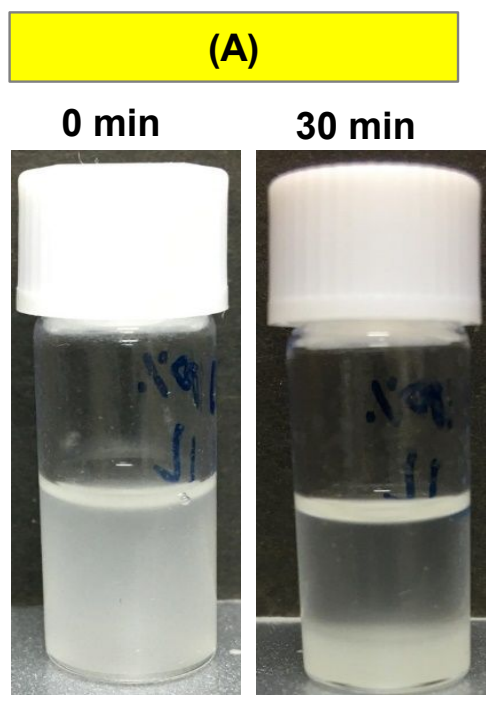

$30 \mathrm{~min}$

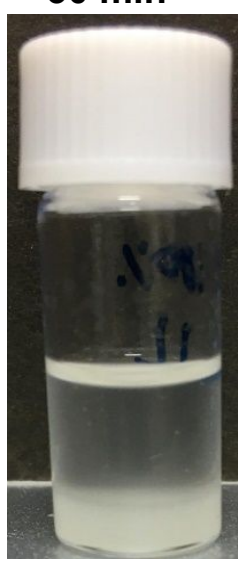

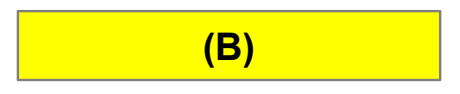

(B)

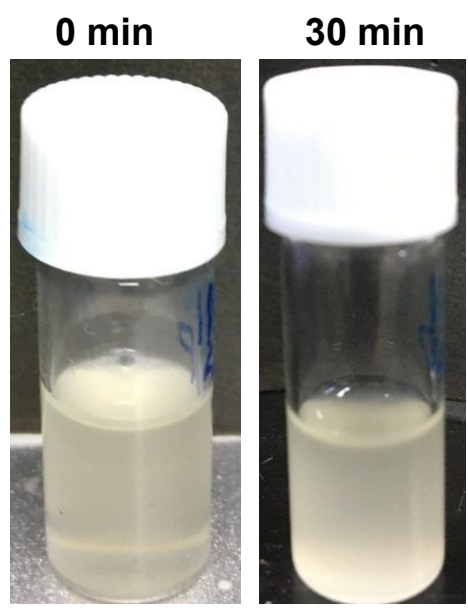

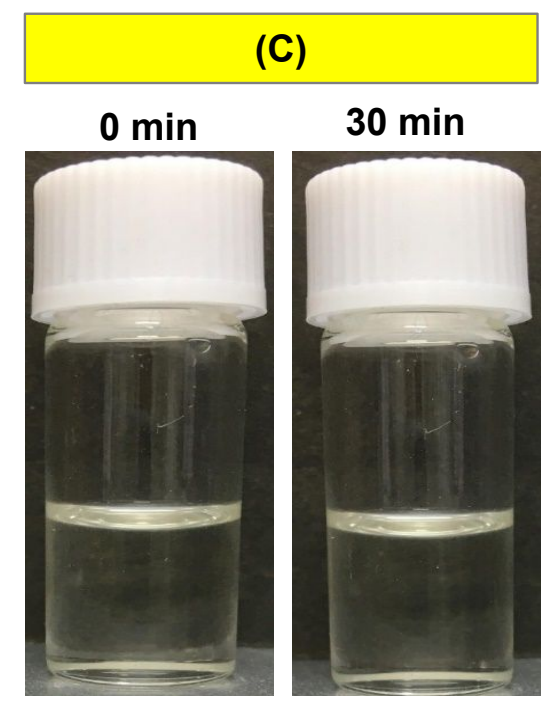

Figure S2: Synergistic micellization by mixtures of SAIL[Cho][Ole] and Span-20. Samples of IPM is micellized using either SAIL[Cho][Ole] alone-(A), Span-20 alone-(B), or a 2:1 mixture of SAIL[Cho][Ole]/ Span-20-(C). Photographs are shown in each case for the sample immediately after preparation by vortex mixing and $30 \mathrm{~min}$ after the cessation of vortex mixing. Note that in (A) and (B) the micelles destabilize and rapidly separates/aggregates. However, in the case of $(\mathrm{C})$, the micelles remain stable and no such separation is seen after $30 \mathrm{~min}$. 

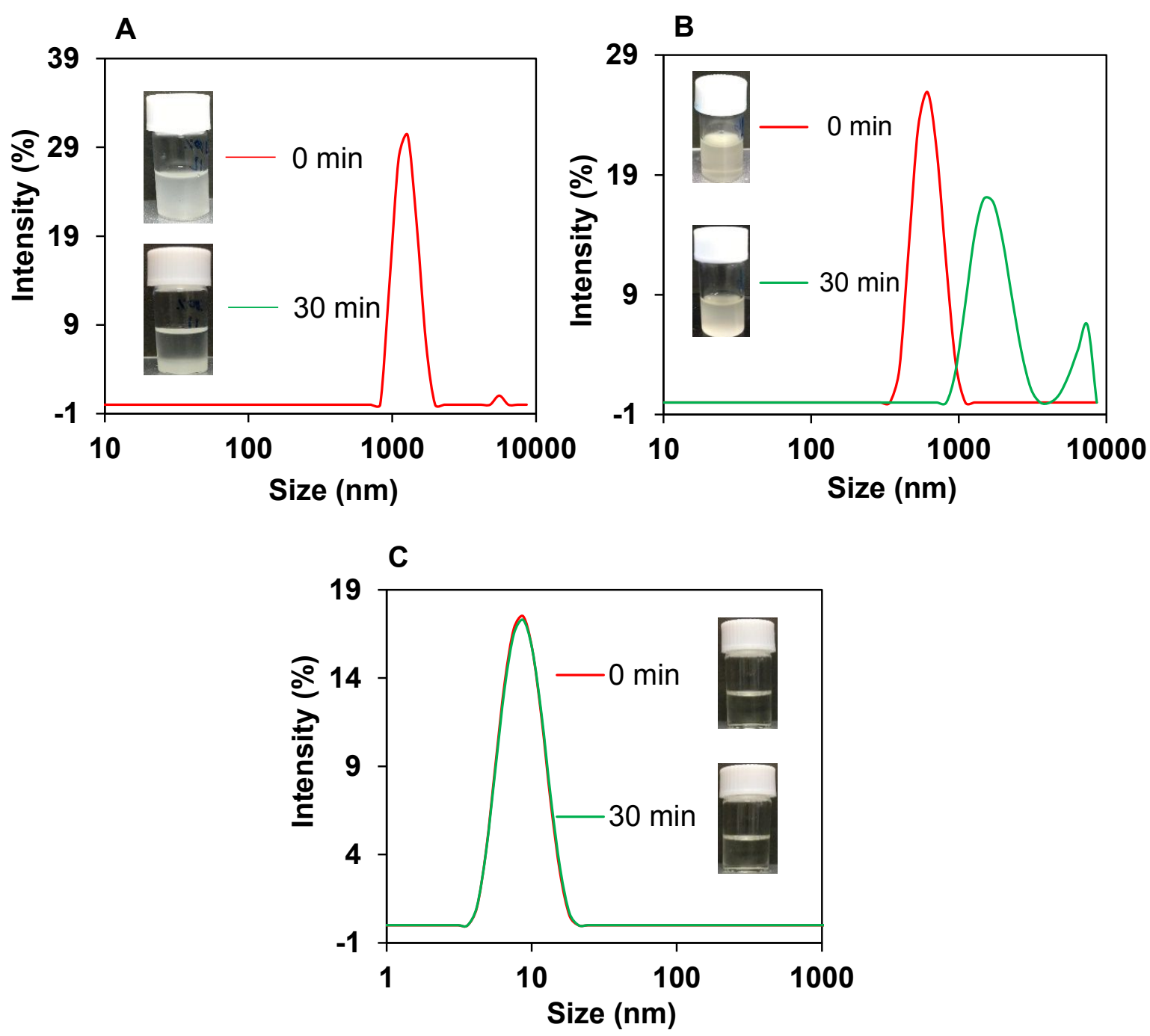

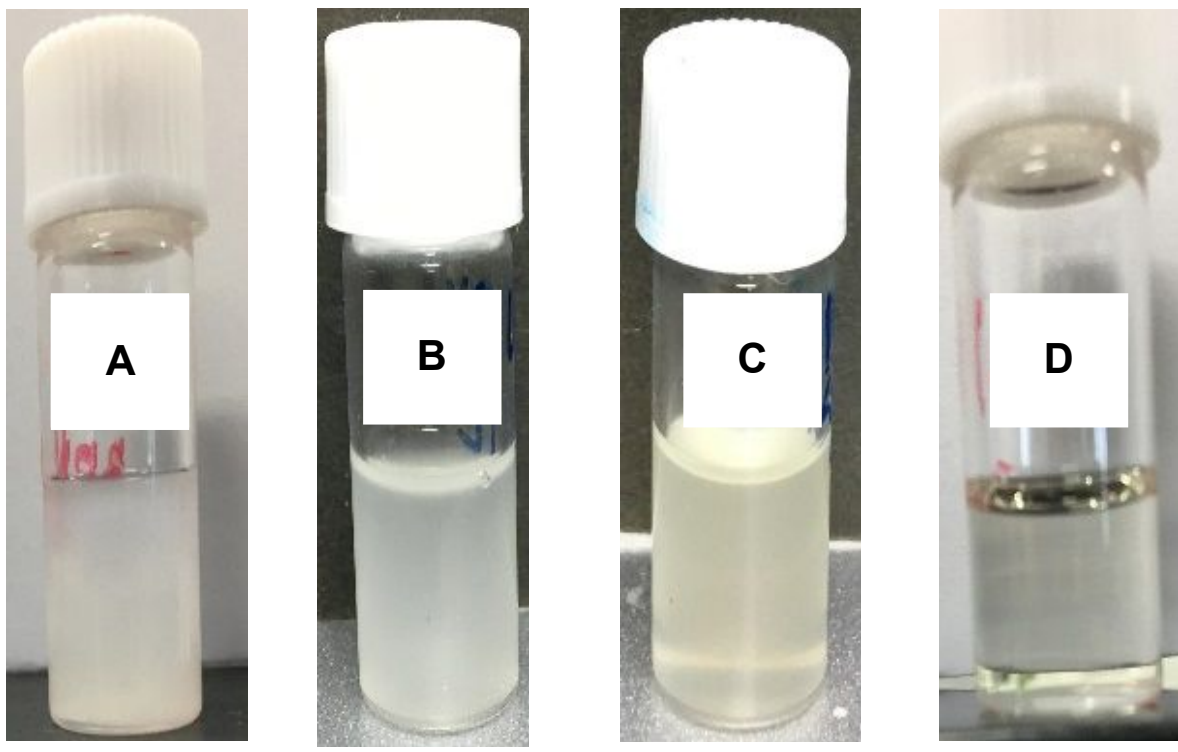

Figure S4. Visual observation of the different formulations

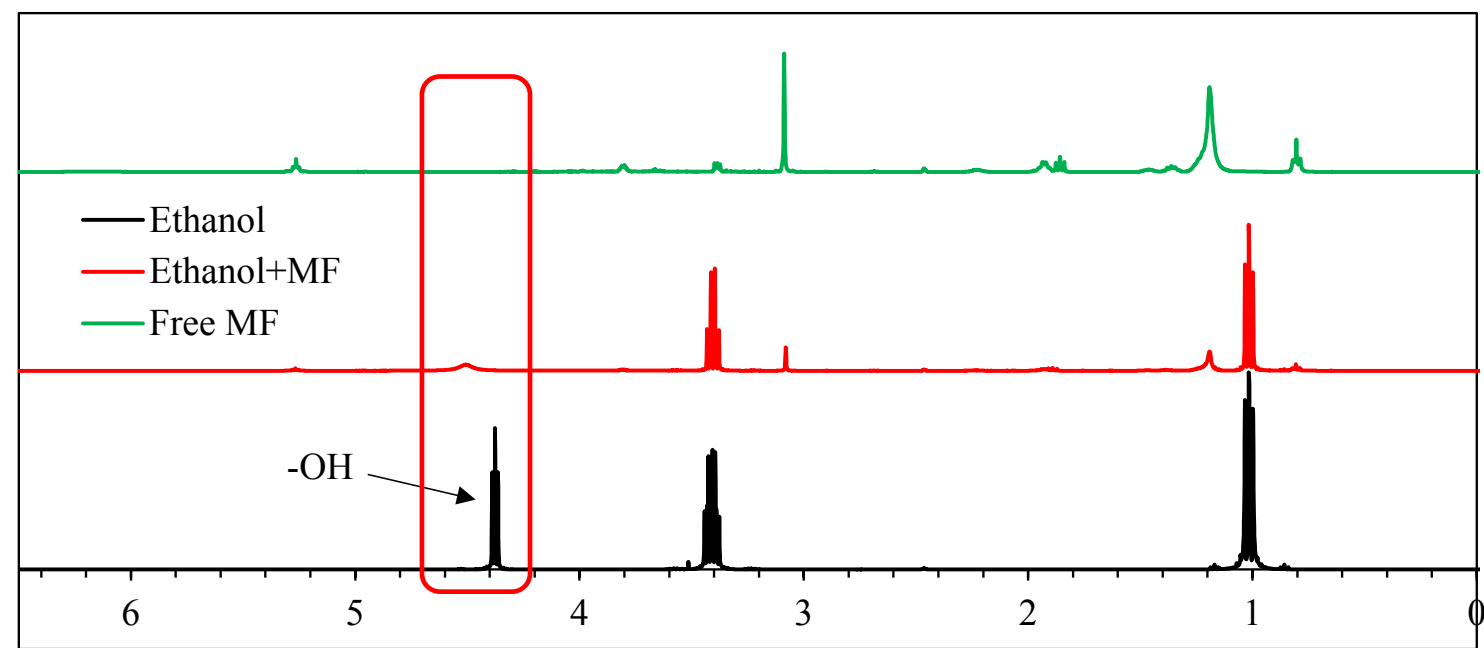

Figure S5. 1H NMR spectra of pure ethanol, ethanol+MF and free MF in DMSO-d6. 


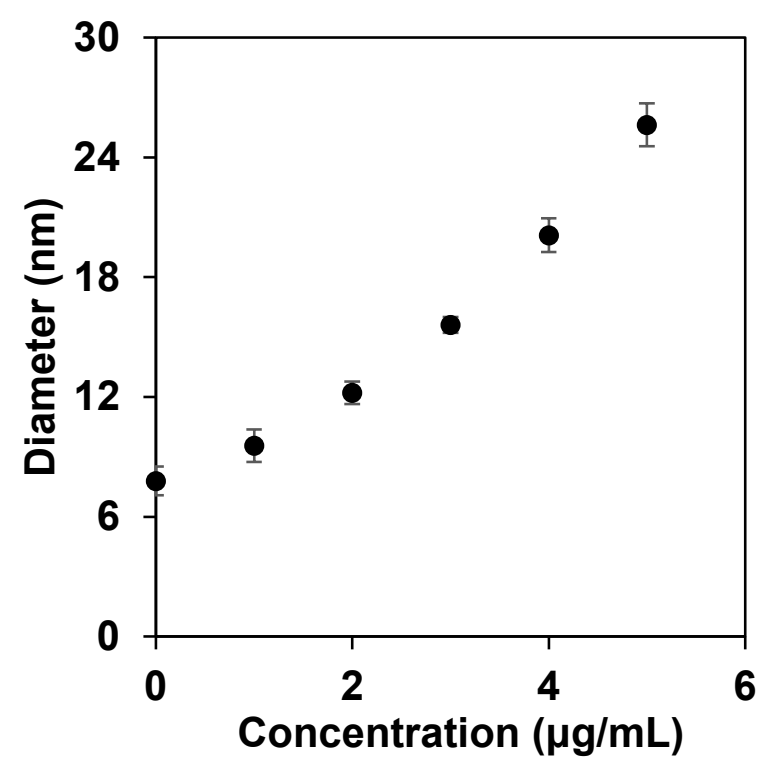

Figure S6: The hydrodynamic diameter of particles with increasing PTX in MFs.

Physical stability of PTX loaded MF

127

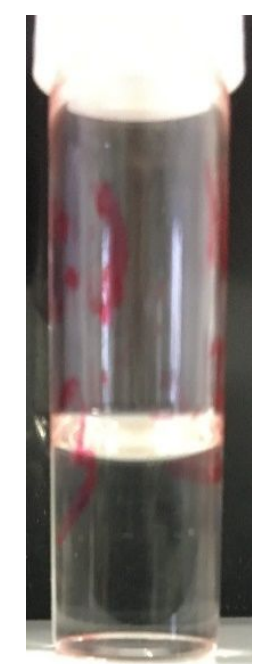

Day1

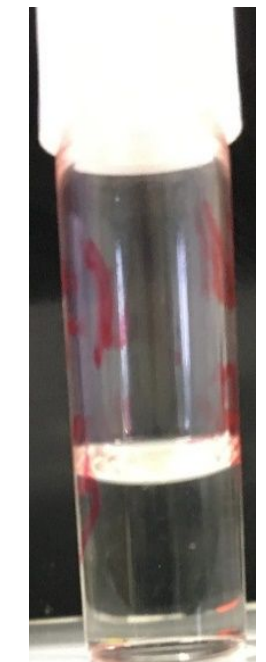

Day30

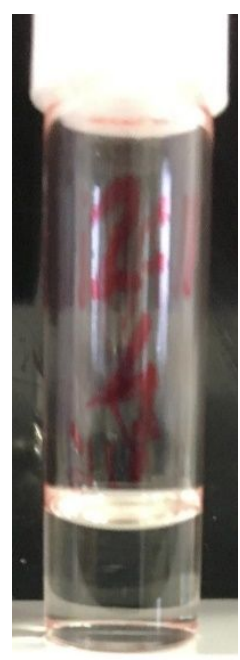

Day60

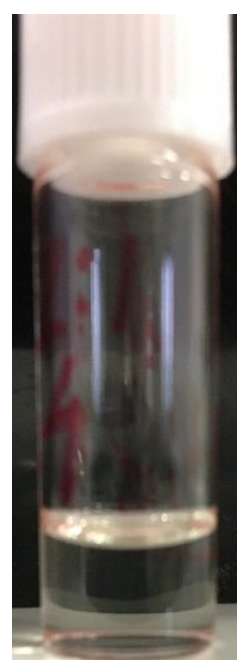

Day90

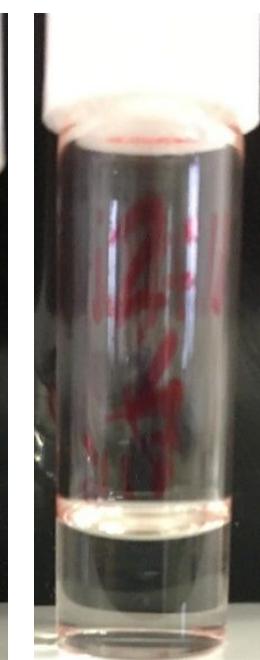

Day120

Figure S7: Visual observation of the MF to evaluate physical stability. 


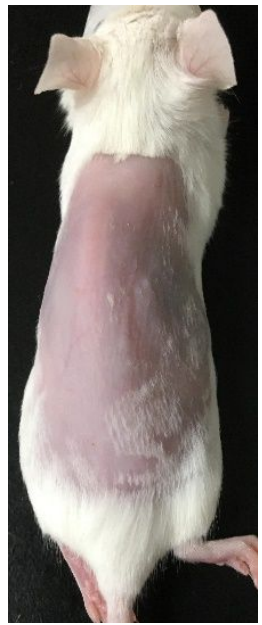

Live

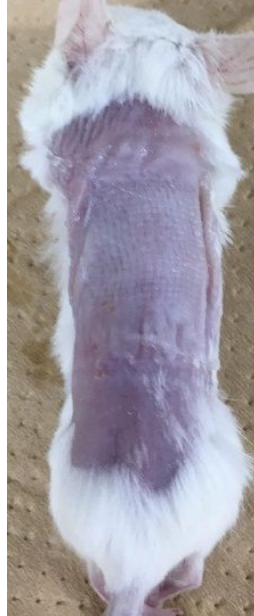

Dead
135

136

137

138

139

4

Figure S8: Physical change like change of color and structure of skin between live and dead mice.

\section{Location of PTX in MF}

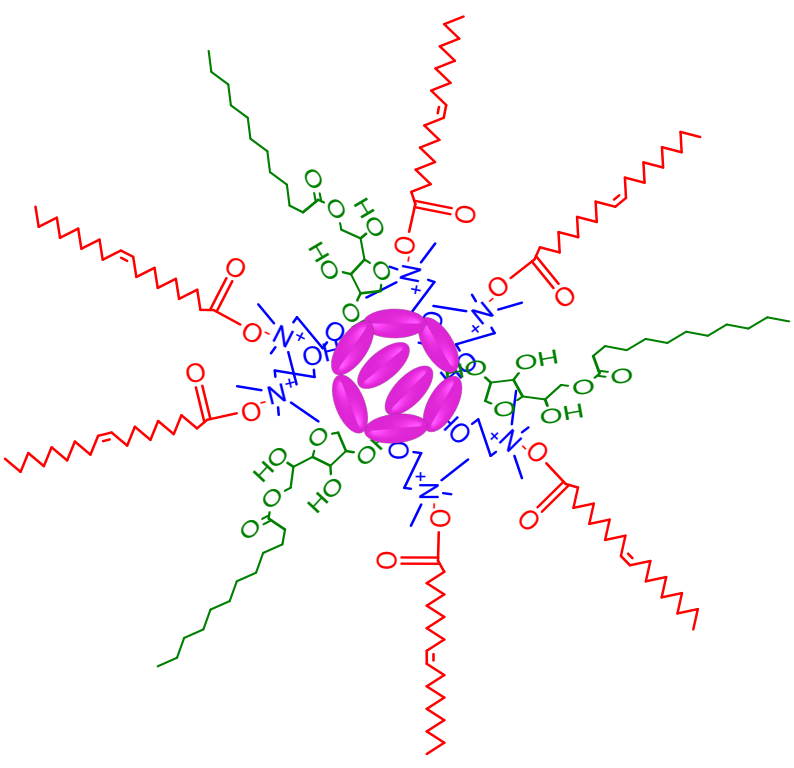

Figure S9: Possible location of adsorption of PTX (0) molecules in micelles.

5

\section{6}




\section{References}

(1) Ali, M. K.; Moshikur, R. M.; Wakabayashi, R.; Tahara, Y.; Moniruzzaman, M.; Kamiya, N.; Goto, M. Synthesis and Characterization of Choline-Fatty-Acid-Based Ionic Liquids: A New Biocompatible Surfactant. Journal of Colloid and Interface Science 2019, 551, 72-80. https://doi.org/10.1016/j.jcis.2019.04.095.

152

(2) Zavgorodnya, O.; Shamshina, J. L.; Mittenthal, M.; McCrary, P. D.; Rachiero, G. P.; Titi, H. M.; Rogers, R. D. Polyethylene Glycol Derivatization of the Non-Active Ion in Active Pharmaceutical Ingredient Ionic Liquids Enhances Transdermal Delivery. New Journal of Chemistry 2017, 41 (4), 1499-1508. https://doi.org/10.1039/c6nj03709g. 